\title{
Early Cretaceous subduction of continental crust at the Diego de Almagro archipelago, southern Chile
}

1 Departamento de Geología, Universidad de Chile, Casilla 13518, Correo 21, Santiago, Chile

2 Research School of Earth Sciences, The Australian National University, Canberra, ACT 0200, Australia.

In the Diego de Almagro archipelago of southern Chile, a quartz rich mica schist and a mylonitized granite contain Late Jurassic zircons of ca 166 and 170 Ma respectively. These rocks were metamorphosed during the Cretaceous in a subduction zone environment, which developed blueschist assemblages in metabasalts interleaved with the mica schist. The dated rocks were probably part of the acid large igneous province developed in southwestern Gondwanaland during the extensional phase which preceded the dismembering of the supercontinent. They constitute evidence that tectonic erosion of the margin occurred, as these siliceous igneous rocks, formed in the South American upper plate, were transported in the subduction zone to some $20 \mathrm{~km}$ depth prior to their exhumation. These rocks are in tectonic contact through the Seno Arcabuz shear zone, with late Permian turbidites of the Duque de York complex, which did not undergo blueschist metamorphism.

\section{Introduction}

In many paleogeographic reconstructions, the western margin of South America, formerly part of the margin of Gondwanaland, is considered to have been an active continental margin for long periods of time. The main testimonies of this tectonic situation are the presence of accretionary wedges with development of blueschists, and subduction related magmatic complexes. However, the preservation of subduction zone complexes is not continuous in time and space along this portion of the Gondwanaland margin. Tectonic erosion of the upper plate margin has often been suggested as a mechanism to explain missing portions of rock belts marginal to the continent. This process implies that parts of the upper plate are detached by the subduction forces and are carried downward, or laterally, along the subduction zone. Tectonic erosion processes have also been considered to explain inland migration of the magmatic foci with time as occurs in central and northern Chile, or to explain evolving geochemical characteristics of suprasubduction zone magmas.

The late Paleozoic to early Mesozoic accretionary complexes which form a belt along the westernmost part of the Andes south of $34^{\circ} \mathrm{S}$, are mainly composed of continent derived metaturbidites, probably deposited in a trench, and of oceanic lithologies, mainly metabasalts and metachert, accreted to the continental margin.

We present geologic and geochronologic evidence that Middle to Late Jurassic acid volcanic and granitic rocks, generated in the continental environment of the upper South America plate as part of an extensive siliceous igneous province, have been carried deep along the subduction zone during the Mesozoic and now form part of the accretionary prism together with the more usual oceanic rock components. Rocks with such a history seem to be unique along the Pacific coast of the Southern Andes, and reveal that tectonic erosion of the leading edge of the continental upper plate has indeed been a process active during the subduction processes at the southwestern margin of Gondwanaland.

\section{Geology}

The geology of the Diego de Almagro archipelago (5130' S; Figure 1) was first described by Cecioni (1955) who identified the presence of large bodies of late Paleozoic limestone associated with metapelite and metabasite. Such rocks characterize most parts of the archipelago. Forsythe (1981) was the first to note the existence of blueschist in the southwestern part of Diego de Almagro island, and considered them to be pre-late Jurassic in age. These blueschists are

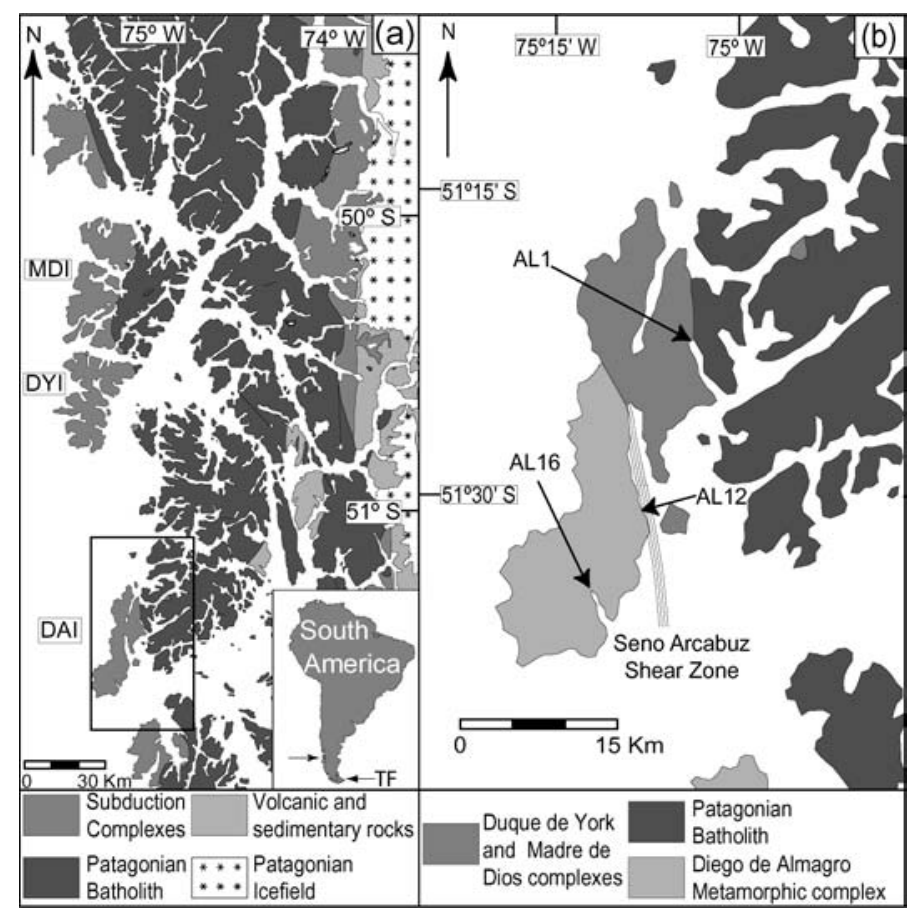

Figure 1 Geologic sketch map of the Diego de Almagro and Madre de Dios archipelagos (a), with indication of sample location (b). Modified from Forsythe (1981). MDI: Madre de Dios Island, DYI: Duque de York Island, DAI: Diego de Almagro Island. 
separated from the less metamorphosed Tarlton limestone and the Denaro and Duque de York complexes by the Seno Arcabuz shear zone (Olivares et al, 2003). The limestone units also exist in the Madre de Dios Archipelago, $100 \mathrm{~km}$ to the north of Diego de Almagro, where their stratigraphy and contact relationships were established by Forsythe and Mpodozis (1979).

The Denaro complex is composed of metabasalt and chert, and it is thought (Ling et al., 1985) to represent contemporaneous ocean floor, basal to the fusulinid bearing Early Permian Tarlton limestone. The latter would have been deposited on a sea mound or on a shallow mid-ocean ridge. Both of these units are unconformably overlain by the turbidite succession of the Duque de York complex (DYC).

The tectonic scenario for the late Paleozoic was summarized by Forsythe (1982) as a west facing active continental margin in which a very wide ("Alaskan type") accretionary complex developed. In this context, the Denaro Complex and the Tarlton limestone are blocks exotic to the South American continent, accreted some time between the early Permian depositional age and the late Jurassic age of intrusion of the earlier phases $(150 \mathrm{Ma}, \mathrm{U}-\mathrm{Pb}$ ages in zircon, unpublished data by the authors) of the South Patagonian Batholith. In this interpretation, the Duque de York Complex was deposited when the Tarlton-Denaro oceanic ensemble approached or entered the subduction zone.

During the Middle to Late Jurassic, a siliceous large igneous province (Pankhurst and Rapela, 1995) developed in the southern Gondwana continents, including South America, in response to crustal anatexis in an extensional environment prior to the opening of the south Atlantic. This province is mainly represented by volcanic rocks, but also has some plutonic counterparts. The most conspicuous is the peraluminous Darwin granite suite in Cordillera Darwin, a muscovite-garnet bearing S-type granite with initial ${ }^{87} \mathrm{Sr} /{ }^{86} \mathrm{Sr}$ ratio of 0.7092 and a $\mathrm{Rb}-\mathrm{Sr}$ isochron age of $157 \pm 8 \mathrm{Ma}$ (Hervé et al, 1979; Hervé et al., 1983), and U-Pb zircon age of 164.1 $\pm 1.7 \mathrm{Ma}$ (Mukasa and Dalziel, 1996). The Darwin granite has been intruded by a basic dyke swarm and then deformed during the mid-Cretaceous (Nelson et al., 1980).

\section{Samples and methodology}

Three rock samples from Diego de Almagro island were collected for SHRIMP ion microprobe U-Th-Pb zircon dating at The Australian National University. Location of the samples is shown in Figure $1 \mathrm{~b}$.

Sample AL1 is a turbidite from the Duque de York Complex. It is a massive medium-grained sandstone forming a $15 \mathrm{~m}$ thick bed, within a succession that also contains some thin continuous pelitic interbeds. Recrystallization is confined to the matrix, and the primary detrital texture is clearly preserved.

Sample AL12 is a mylonitised granite within the Arcabuz Shear Zone, collected from a small island at the entrance of Caleta Olla. It is a foliated and lineated quartz-feldspar rich mylonitic gneiss, from a body of unknown extension. A strong penetrative mylonitic foliation and a NW plunging lineation are present, as in all the rocks along the shear zone. This foliation is crenulated by a later less developed D2 foliation plane. Decimeter thick amphibolite bands are isoclinally folded with the foliation axial planar. Light coloured veins, 5-10 $\mathrm{cm}$ thick, composed by a central quartz-rich band and coarse grained quartz-albite-muscovite margins, are also isoclinally folded, and boudinaged. Amphibolites may represent former basic dykes, the light bands, pegmatitic or hydrothermal veins. In the analysed gneiss, quartz is present in elongated lenses, plagioclase appears as porphyroclasts and is completely transformed to a very fine-grained keliphytic aggregate, almost opaque in thin section. Well oriented large crystals of biotite and muscovite $(\mathrm{Si}=3.25 \mathrm{apfu})$ are present, and the latter have rims of small grain phengite rich ( $\mathrm{Si}$ $=3.6 \mathrm{apfu}$ ) aggregates. Zircon, titanite, and ilmenite are accessory minerals. The rock appears to be a strongly mylonitised granite.
Sample AL16 is a quartz rich mica schist from the western end of Puerto Diego de Almagro, interleaved with blueschists. It is a quartz rich albite, white mica, biotite and garnet well foliated schist. Quartz is present in recrystallized bands and lenses together with albite. The biotite has wavy extinction, and the white mica exists in two different generations: big crystals with $\mathrm{Si}$ apfu contents of 3.1 and smaller crystals, some peripheral to biotite grains, with $\mathrm{Si}=3.5$ apfu, respectively. Garnet occurs as small euhedral crystals.

The SHRIMP analytical procedures follow those summarized in Williams (1998). The age spectra of individual sedimentary rock units can be used to infer the maximum depositional age the original sediments. This inferred age is estimated from the half height of the younger peak of an age vs. cumulative probability plot, recorded by the zircon ages pattern, and represents a maximum possible age of deposition of the rock., as these crystals with igneous characteristics were probably eroded into the trench from young plutonic or volcanic rocks. Samples AL1 and AL16 were initially considered to be metasediments, but the zircon data indicates that AL16 is very probably an acid volcanic igneous rock. Crystallization ages can be obtained for igneous rocks, as sample AL12 was suspected to be. Weighted mean ages reported are radiogenic ${ }^{206} \mathrm{~Pb} / 238 \mathrm{U}$ ages, at the $95 \%$ confidence level.

\section{Geochronology}

\section{Previous data}

Hervé et al. (1999) mention in part some of the U-Pb zircon data discussed below. Additionally, they reported Ar-Ar ages of ca $120 \mathrm{Ma}$ and $89 \mathrm{Ma}$ respectively for the two generations of white mica in the AL 12 mylonitic granite, and K-Ar ages of 122 to $128 \mathrm{Ma}$ for blue amphiboles from the blueschists of the Diego de Almagro Metamorphic Complex (DAMC). These data indicate that the blueschist metamorphism occurred during the Early Cretaceous, extending into the earliest Late Cretaceous after the Gradstein and Ogg (1996) geological time scale.

\section{New data}

The SHRIMP U-Th-Pb data are presented in Figures 2 and 3. Figure 2 presents cathodoluminescence (CL) images of selected grains within the studied samples, and Figure 3 the age versus probability diagrams.

The age spectra for the sandstone from the Duque de York complex, sample AL1, is dominated by a prominent cluster of grains with concordant $\mathrm{U} / \mathrm{Pb}$ ages at about $270 \mathrm{Ma}$ (Figure 3a). In detail, this broad age peak can be resolved into discrete sub-sets with weighted mean ${ }^{206} \mathrm{~Pb} / 238 \mathrm{U}$ ages of $265 \pm 3 \mathrm{Ma}, 279 \pm 3 \mathrm{Ma}$ and 298 $\pm 4 \mathrm{Ma}$. There are less prominent groupings at ca $400 \mathrm{Ma}$ and ca 480 $\mathrm{Ma}$, with a few scattered Proterozoic grains. From the age spectrum and dominance of the ca 270 Ma grains we interpret a maximum depositional age of late Early Permian.

The zircon population from the quartz mica schist sample $\mathrm{Al} 16$ (Figure 3b) is dominated by zoned magmatic zircon (Figure 2a) and these yield a concordant cluster of analyses at around $170 \mathrm{Ma}$. There are only two significantly older grains in the fifty analysed, including one Proterozoic zircon. Twenty six of the analyses have a weighted mean ${ }^{206} \mathrm{~Pb} / 238 \mathrm{U}$ age of $166 \pm 2 \mathrm{Ma}$. There are possible minor age groupings, one reasonably well defined at $174 \pm 2 \mathrm{Ma}$ (10 grains), with subordinate groupings at ca $183 \pm 4 \mathrm{Ma}$ (7 analyses) and $157 \pm 3$ Ma (5 analyses).

The mylonitised granite sample AL12 has a complex age probability pattern (Figure $3 \mathrm{c}$ ), which in part may be consequence of the high proportion of structured zircon grains. Approximately $60 \%$ of the grains have high $\mathrm{U}$, low $\mathrm{Th} / \mathrm{U}$ zircon overgrowths clearly evident in the CL images (Figure 2b). For many other grains these rims are present, but are less than 10 um in width and were not analysed in this study. The overgrowths analysed form a distinctive concordant 


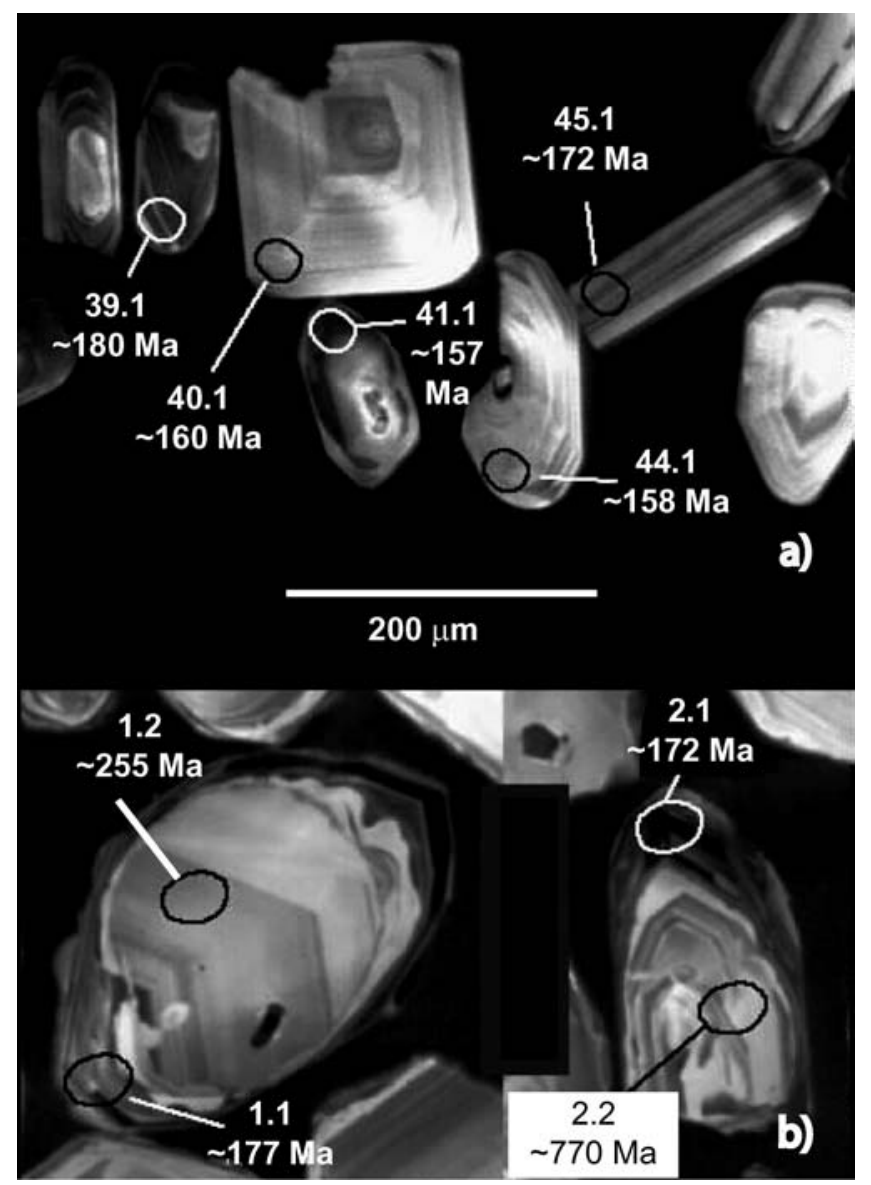

Figure 2 Cathodoluminescence image of a) igneous crystal (schist AL16) and b) igneous rim (gneissic granite AL12) of Jurassic age.

age group at ca $170 \mathrm{Ma}$, similar in age to the main population recorded in the schist. Another prominent age grouping is at ca 280 $\mathrm{Ma}$, all of which correspond to the analyses of core areas. The ca 290 Ma age group is also similar to one recorded in the sandstone spectra, as is a smaller age peak at ca $400 \mathrm{Ma}$. However, a distinct peak at ca $540 \mathrm{Ma}$ in the granite has no counterpart in the sandstone and older (Proterozoic) grains are more common than in the sandstone and in the schist.

\section{Discussion}

The data presented here indicate that the depositional age of the Duque de York complex is probably Late Paleozoic, i.e. much older than the igneous crystallization age of the precursors of the schist and granite gneiss analyzed from the Diego de Almagro Metamorphic complex.

In the latter, both rocks contain Middle to early Late Jurassic zircon age components, represented in the schist by the age of discrete magmatic zircon crystals, whereas in the granite this is the age for zoned magmatic zircon rims. The igneous nature of the schist zircons is quite evident due to the fine zoning and the euhedral crystal morphology. The relative homogeneity of the zircon age population in the schist is interpreted as indicating a magmatic precursor rock, rather than a sedimentary protolith, where a greater dispersion of $\mathrm{U}$ $\mathrm{Pb}$ zircon ages is more common. The rather low temperatures attained during the metamorphism of this unit, probably around 480 to $520^{\circ} \mathrm{C}$ (Willner et al, submitted), make it improbable that new zircon growth occurred during the metamorphic event.

The rims formed on many of the AL 12 granite gneiss zircon crystals are also igneous in origin, as the CL images show that many have concentric zoning. Further, the AL12 mylonitised granite has a zircon age spectra which in its younger (> $200 \mathrm{Ma},<500 \mathrm{Ma})$ part matches that of the Duque de York detrital (AL1) zircon age spectra, but differs from the latter, containing a major 540 Ma component.. This last age is very similar to those obtained by Sollner et al. (2000) from orthogneisses found at the termination of oil wells in Tierra del Fuego, some hundreds of kilometers east of the Diego de Almagro area (See Figure 1 for location). The existence of zircon grains of this age in Diego de Almagro suggests that those rocks, or sediments
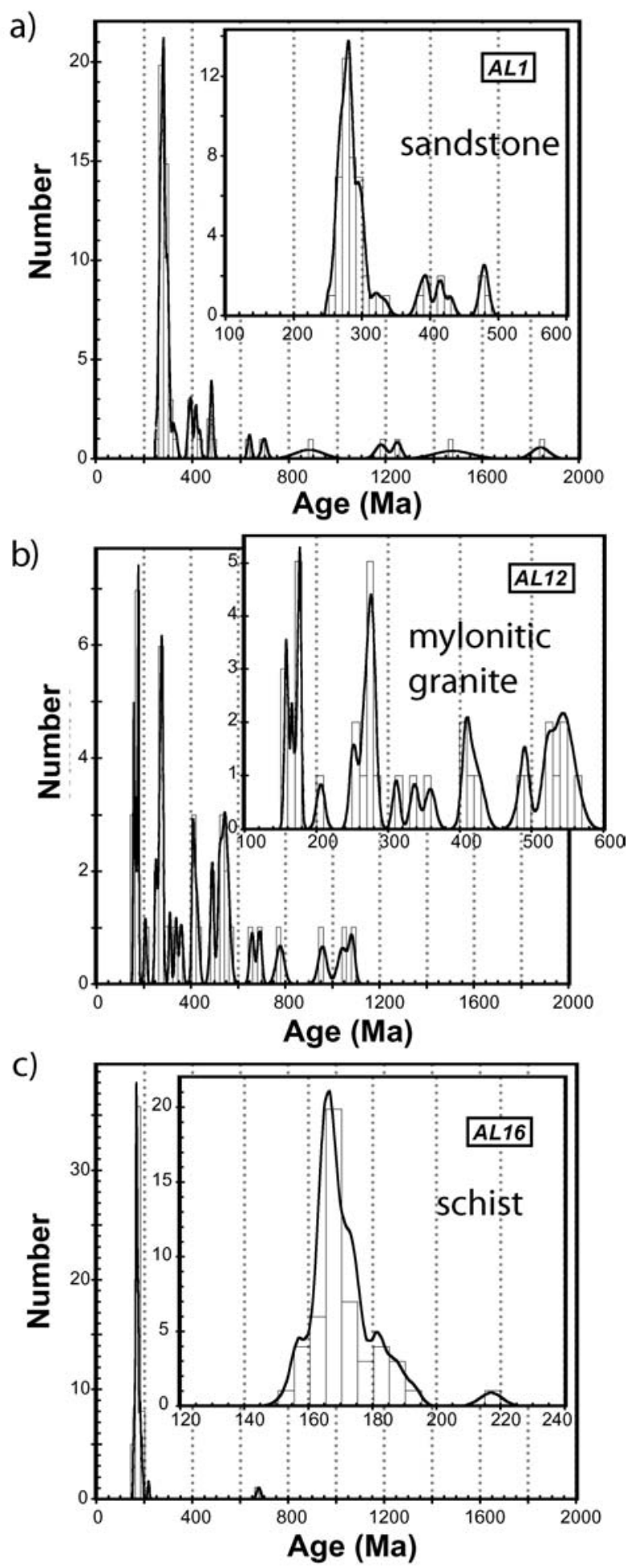

Figure 3 Age vs probability diagrams for a) DYC sandstone (AL1), b) DAMC gneissic granite (AL12) and c) DAMC schist (AL16). Analytical data for U-Pb SHRIMP ages in Tables 1 to 3 of the Episodes repository data bank. 
derived from such rocks, extended to the present western edge of the continent during the Middle Jurassic. The AL12 precursor granite could have incorporated its younger zircon components (cores) from contamination from the Duque de York Complex (DYC) and the older Early Cambrian crystals from contamination from an infrajacent (?), not presently exposed unit

The possibility of the granite being an S-type granite, which involved melting of one or both of the units above, is favoured in this paper. The modal relic primary mineralogy including muscovite and garnet ,the extended age spectra of the zircon grains, as well as their $\mathrm{U}$ rich and $\mathrm{U} / \mathrm{Th}$ poor composition suggest an anatectic origin. Other muscovite-biotite-garnet bearing granites with similar age exist in the region, as is the case of the Darwin granite suite (Hervé et al., 1980; Mukasa and Dalziel, 1996). The latter has a high (0.7092) Sr initial ratio and has also been interpreted as the result of anatexis of continental crust during the formation of the Middle to Late Jurassic large siliceous igneous province in southwestern Gondwanaland. On the other hand, the subduction related granitoids which constitute the South Patagonian Batholith, have Sr initial ratios between 0.703 and 0.705 , usually a hornblende-biotite dominated mineralogy, and ages $150 \mathrm{Ma}$ or younger, as indicated by Bruce et al (1991) and our unpublished data.

The absence of older zircons in the schist sample could have been caused by a differentiation episode in a high temperature magmatic chamber, within which only newly formed igneous zircons were preserved. The intercalation of this rock with the blueschists is either tectonic, or it indicates that the original rock could have been deposited, maybe as an ash fall deposit on ocean floor adjacent to Gondwanaland which is now represented by the mafic blueschist rocks .

Both the quartz rich mica schist (AL 16) and the mylonitised granite (AL 12) contain two generations of white mica, the younger and more phengitic one (up to $3.6 \mathrm{Si}$ a.p.f.u) being indicative of high pressure and low temperature metamorphism after the phengite geobarometer of Massone and Szpurka ( 1997 ), and the thermodynamic calculations in Willner et al (submitted). The chemical composition of the white micas is in the same range as that shown by the white micas in the mafic blueschists (Willner et al., submitted), a very probable indication that they have a common high pressure - low temperature metamorphic history in the subduction zone environment.

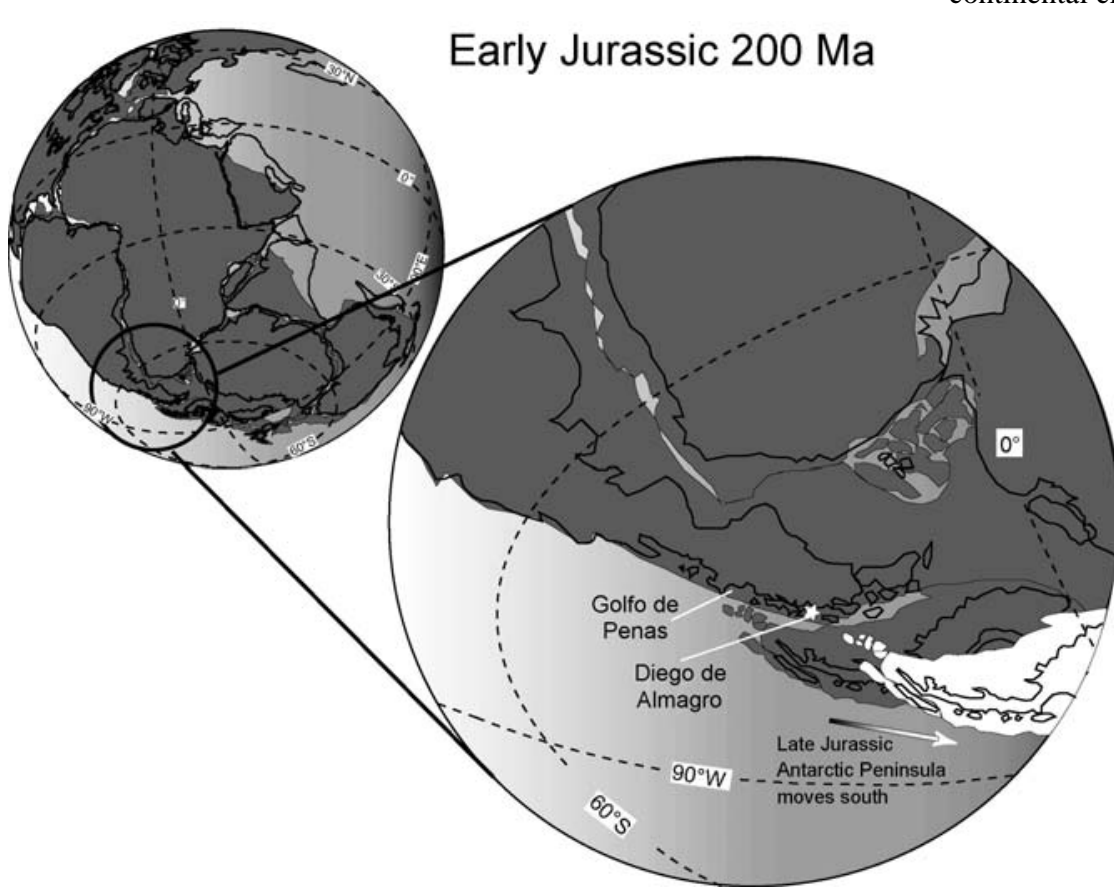

Figure 5 Paleogeographic reconstruction modified from Scotese (1997) to show the tip of the Antarctic Peninsula at the present latitude of $45^{\circ} S$ during the Early Jurassic as shown in Lawver et al. (1998). White star shows the location of Diego de Almagro.

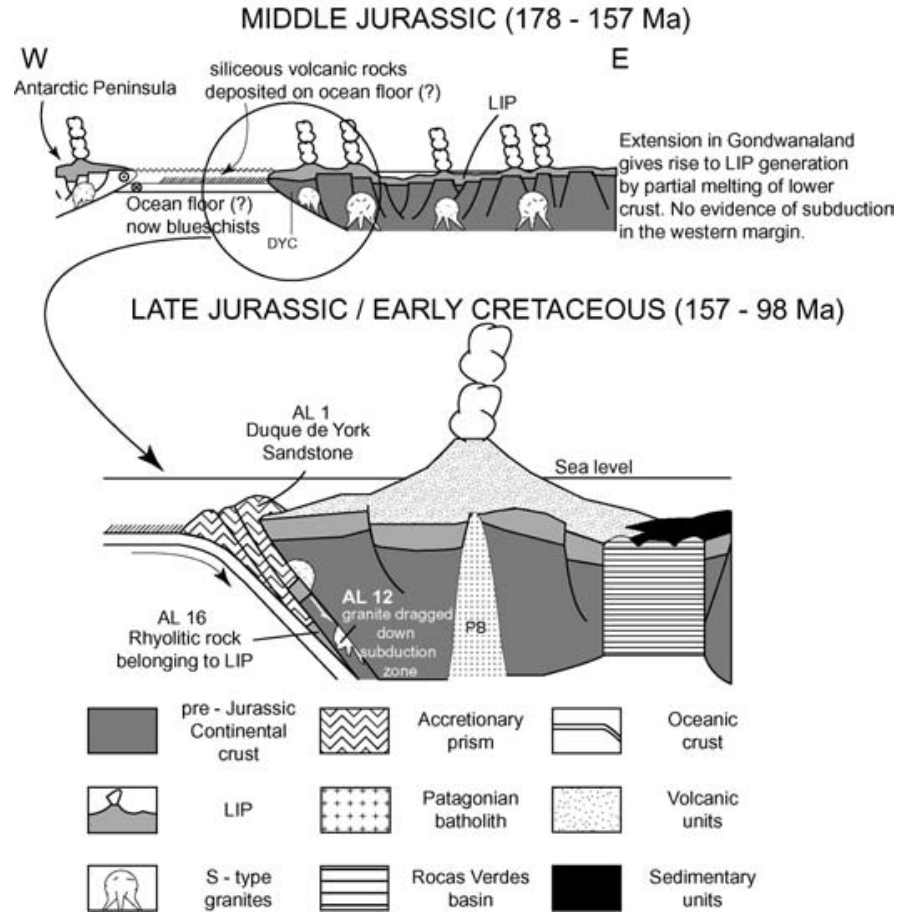

Figure 4 Cartoon with tectonic interpretation in cross sections at the latitude of Diego de Almagro.

\section{Tectonic interpretation}

A widespread event of lower crustal anatexis took place in southern South America, in the Middle to Late Jurassic associated with extension that preceded the breakup of Gondwanaland. The igneous protoliths of the gneiss and schist studied here were probably generated during this event, as indicated by the ca $170 \mathrm{Ma}$ age zircons in both, the relic peraluminous mineralogy and the population of inherited zircons in the granite gneiss which suggest an origin by melting of continental crust. These continental rocks were then subducted to at least $20 \mathrm{~km}$ depth as indicated by the high phengite content in their second generation of white mica. The process of tectonic (subduction) erosion of the continental margin took place in the Cretaceous, as indicated by the the K-Ar mineral ages in the blueschists (122 and $128 \mathrm{Ma}$ ) and the Ar-Ar ages of the muscovite (120 Ma) and of its phengitic rims ( 89 $\mathrm{Ma}$ ) in the mylonitic gneiss. No zircon growth of these younger ages has been observed in the studied rocks.

These relationships indicate that the initiation of subduction in the area took place after the production of the siliceous anatectic rocks, which were entrained deep into the subduction zone together with the mafic blueschists. The regional initiation of subduction can be dated at ca $150 \mathrm{Ma}$, the oldest ages in the calc-alkaline south Patagonian Batholith, and the subduction was active during the generation of the main body of the batholith, 120 to $70 \mathrm{Ma}$ (Bruce et al, 1991). A possible scenario for the geologic evolution of the area, which changed from a rather inboard setting in the Middle Jurassic to a active margin setting at $150 \mathrm{Ma}$, is schematically shown in section and plan view in Figures 4 and 5 respectively. In them, the Antarctic Peninsula is shown in a very northern position outboard of the western margin of South America, as suggested by the tight fit reconstruction of Gondwanaland by 
Lawver et al (1998). This position of the Antarctic Peninsula implies that during the Early and Middle Jurassic, the Diego de Almagro area was not in the westernmost part of the continental margin, and only when the Antarctic Peninsula started drifting to the South, could subduction directly involve the rocks reported here. The necessary left lateral strike slip motion of the Antarctic Peninsula is in full agreement with the kinematics of the Seno Arcabuz shear zone as determined by Olivares et al (2003).

\section{Acknowlegements}

This research was financed by FONDECYT Projects 1980741 and 1010412 to F.H. Captain V. Alvarez in the cutter "21 de Mayo" took us to these remote regions. Discussions with R.J. Pankhurst and J. Bradshaw, among others, triggered many of the ideas presented. V. Faúndez prepared the figures.

\section{References}

Bruce,R.M., Nelson,E., Weaver, S.G. and Lux, D.R. 1991, Temporal and spatial variations in the southern Patagonian batholith; Constraints on magmatic arc development, In Harmon,R.S. and Rapela,C.W. eds., Andean magmatisma and its tectonic setting: Boulder, Colorado, Geological Society of America Special Paper 265, p.1-12.

Cecioni, G., 1956, Primeras noticias sobre la existencia de Paleozoico Superior en el Archipiélago Patagónico entre los paralelos 50 y $52 \mathrm{~S}$, Universidad de Chile, Facultad de Ciencias Físicas y Matemáticas, Anales, v. 13, p. 471-496.

Forsythe,R., 1981, Geological investigations of pre-Late Jurassic terranes in the sothernmost Andes. Ph.D. Thesis, Columbia University, 298 p., New York.

Forsythe, R., 1982, The late Paleozoic and Early Mesozoic evolution of southern South America: A plate tectonic interpretation, Journal of the Geological Society of London, v. 139, p. 671-682.

Forsythe, R.D. and Mpodozis, C., 1979, El Archipiélago Madre de Dios, Patagonia Occidental, Magallanes: rasgos generales de la estratigrafİa y estructura del basamento pre Jur-sico Superior. Revista Geológica de Chile, 7, p. 13- 29.

Hervé, F., Nelson, E. \& M. Suárez (1979). Edades radiométricas de granitoides y metamorfitas de Cordillera Darwin, XII Región, Chile. Rev. Geológica de Chile ,7, 31-40.

Hervé, F., Nelson, E., Kawashita, K. \& Suárez, M., 1981, New isotopic ages and the timing of orogenic events in the Cordillera Darwin, southernmost Chilean Andes, Earth \& Planetary Science Letters, 55, 257-265.

Hervé, F., Prior, D., López, G., Ramos, V.A., Rapalini, A., Thomson, S., Lacassie, J.P. and Fanning, M., 1999, Mesozoic blueschists from Diego de Almagro, southern Chile, II South American Symposium on Isotope Geology, Actas, (Extended Abstract), p.318-321, Córdoba.

Ireland, T. R., 1992, Crustal evolution of New Zealand: evidence from age distributions of detrital zircons in Western province paragneisses and Torlesse greywacke, Geochimica et Cosmochimica Acta, v. 56, p. 911-920.

Lawver, L. A., Dalziel, I. W. D., Gahagan, L. M., 1998, A tight fit Early Mesozoic Gondwana, a plate reconstruction perspective. Memoirs of the National Institute for Polar Research, Special issue, Vol.53, p.214-229, Tokyo.
Ling, H.Y., Forsythe, R.D. and Douglass, C.R., 1985, Late Paleozoic microfaunas from Southernmost Chile and their relation to Gondwanaland forearc development, Geology, v. 13, p.357-360.

Massone, H.J. and Szpurka, Z., 1997, Thermodynamic properties of white micas on the basis of high-pressure experiments in the systems $\mathrm{K}_{2} \mathrm{O}-$ $\mathrm{MgO}-\mathrm{Al}_{2} \mathrm{O}_{3}-\mathrm{SiO}_{2}-\mathrm{H}_{2} \mathrm{O}$ and $\mathrm{K}_{2} \mathrm{O}-\mathrm{FeO}-\mathrm{Al}_{2} \mathrm{O}_{3}-\mathrm{SiO}_{2}-\mathrm{H}_{2} \mathrm{O}$. Lithos, 41, $229-250$.

Mukasa, S. and Dalziel, I.W.D., 1996, Southernmost Andes and South Georgia Island, North Scotia Ridge: zircon U-Pb and muscovite $\mathrm{Ar}-\mathrm{Ar}$ age constraints on tectonic evolution of southwestern Gondwanaland. Journal of South American Earth Sciences, v. 9, p. 349-365.

Muir, J., Ireland, T.R., Weaver, S.D. and Bradshaw, J.D., 1996, Ion microprobe dating of Paleozoic - Devonian magmatism in New Zealand and correlation with Australia and Antarctica. Chemical Geology, v. 17, p. 191-210.

Nelson, E., Dalziel, I.W.D. and Milnes, A.G., 1980, Structural geology of the Cordillera Darwin: Collision style orogenesis in the southernmost Chilean Andes, Eclogae Geologicae Helveticae, v. 73, p. 727-751.

Olivares,B., Cembrano, J., Hervé, F., López, G., Prior, D., 2003, Geometría y cinem.tica de la Zona de Cizalle Seno Arcabuz, Andes patagÛnicos, Chile. Revista Geológica de Chile, Vol. 30, N.1, 39-52.

Pankhurst ,R.J. and Rapela, C., 1995, Production of Jurassic rhyolite by anatexis of the lower crust of Patagonia, Earth and Planetary Science Letters, v.134, p. 23-36.

Scotese,C.R., 1997, Phanerozoic plate tectonic reconstructions, PALEOMAP Progress Report 90-0947, Department of Geology, University of Texas, Arlington, USA.

Sollner, F., Miller, H., and Hervé, M., 2000, An Early Cambrian granodiorite age from the pre-Andean basement of Tierra del Fuego (Chile): the missing link between South America and Antarctica? Journal of South American Earth Sciences, 13,163-177.

Williams, I.S., 1998, U-Th-Pb geochronology by ion microprobe, In McKibben, M.A. and Shanks, W.C. eds., Applications of microanalytical techniques to understanding mineralizing processes, Reviews in Economic Geology, 7, 1-35.

Willner, A.P., Hervé, F., Thomson, S.N., \& Massonne, H.-J.(2003), Converging PT-paths of different HP-LT metamorphic units within a Mesozoic accretionary belt (Diego de Almagro Island, Southern Chile, 5130' S): Evidence for juxtaposition during late shortening of an active continental margin. (Submitted, Contributions to Mineralogy and Petrology, October 2003).

Francisco Hervé is Professor at Departamento de Geología, Universidad de Chile, at Santiago, and Member of the Chilean Academy of Science. He served as Vice President of IUGS from 1992 to 2000. He works on the evolution of metamorphic complexes in Patagonia and west Antarctica, with a multidisciplinary and multinational research group he has contributed to establish.

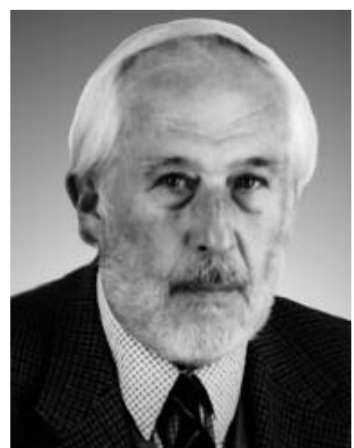

